\title{
EVALUATION OF TOMATO INBREED LINES FOR RESISTANCE TO ROOT-GALL NEMATODE
}

\author{
El-Nuby, Ahmed S.M. ${ }^{*}$ and Khaled E.M. Bayomi ${ }^{2}$ \\ ${ }^{1}$ Department of Plant Protection, Desert Research Center, El- \\ Matareya, Cairo, Egypt \\ ${ }^{2}$ Department of Genetic Resources, Desert Research Center, El- \\ Matareya, Cairo, Egypt \\ *E-mail: ahsomama@gmail.com
}

C creening of 51 tomato inbreed lines, obtained from Tomato $\checkmark$ Breeding Program of Desert Research Center (DRC), was carried out in two different times varied in temperature, early winter and summer during 2018-2019, to evaluate the reaction of these genotypes towards infection with root-gall nematode (RGN) Meloidogyne incognita. The response of these inbreed lines was varied between resistance (R) and highly susceptible (HS) based on galls number (G) and egg masses index (E.M.I.), also egg production was a dependable factor. Two genotypes viz., SA174-7 and SY174-1 found to be R according to G and E.M. formed 2 galls and 1 egg mass and 12 galls and 1 egg mass, respectively. The moderately resistant genotypes were SK174-4, SW174-4 and SY174-8-3, while the three genotypes SC174-7, SD174-4-1 and SY174-2-2 found to be moderately susceptible. About $14 \%$ of tested genotype were susceptible, while the rest inbreed lines (70\%) were HS. It was clearly noticed that temperature (summer and winter trials) has an impact on nematode penetration and reproduction, but its effect in genotype resistance ranking was absent in a few cases. Finally, data obtained from this screening open the way to further evaluations and detection of the genetic diversity of the most resistance genotypes for improving new inbreed lines bearing more desirable characters, in particular high yield with resistance to RGN, and try to identify the genes that conferring resistance to transfer it to susceptible genotypes.

Keywords: root-gall nematode, Meloidogyne, tomato, resistance, inbreed lines

Phytoparasitic nematodes are devastating plant pathogens in Egypt and many tropic countries. Globally, plant parasitic nematodes (PPN) are destructive pests of tomato and cause tremendous losses (Bird and The $1^{\text {st }}$ Conference of Plant Protection Science Applications for Sustainable Development of Desert Areas "Effect of Climate Change on Plant Pests and Biodiversity in Desert Environment" 19-20 October, 2019, Cairo-Egypt. 
Kaloshian, 2003). The root-gall nematodes (RGN) Meloidogyne spp. represent the most polyphagous genus of PPN, about 100 species were recognized under this genus and the major species are $M$. arenaria, $M$. hapla, M. incognita and M. javanica. RGN considers one of the most serious pests of many economic field and vegetable crops (Ibrahim et al., 2010 and Elling, 2013). In many subtropical countries as Egypt, the RGN nematodes are widely spread and infect many vegetable crops including tomato, severe infection with RGN causing decrease in the quantity and quality of tomato yield as well as the marketable rank will reduce (Ibrahim et al., 1999 and 2010; Sikora and Fernandez, 2005 and Sujatha et al., 2017). Meloidogyne incognita is a major pest of tomato and responsible for deteriorating the yield of tomato crop and fruit quality (Bufokuzara, 1996). It causes noticeable reduction in tomato yields and heir globally estimated yield losses may reach to 5\% (Anwar and McKenry, 2010 and Cetintas and Yarba, 2010). In tropical and subtropical regions, the tomato yield losses ranged between 30 to $40 \%$ (Charchar et al., 2003).

Effective control of PPN is costly and mainly depending on nematicides, but they cause many hazards effects to living organisms and consequently restricted in many countries (Fosu-Nyarko and Jones, 2015). The use of resistant genotypes is promising manner of controlling plant pathogenic nematodes because they are a cheap and effective control tool, but they require time and some facilities to develop resistant hybrids and reaching to genetic stability, also screening and evaluating them to create certified cultivars suitable for certain area and nematode population in this area.

The goal of the current research aims to evaluate some tomato genotypes for resistance to root-knot nematode (RKN), Meloidogyne incognita, in two different seasons (cold and warm).

\section{MATERIALS AND METHODS}

\section{Stock Culture of Root-knot Nematode}

Pure culture of Meloidogyne incognita obtained from infected tomato roots was established. Single egg-mass from previously identified females was used to inoculate three weeks old of healthy tomato cv. Castel Rock grown in $20 \mathrm{~cm}$ clay pots filled with sterilized soil. After six weeks from inoculation, plants were investigated for forming egg masses then further inoculation for healthy tomato seedlings was carried out. The culture was kept on clean benches in greenhouse of Plant Protection Department, DRC, and continuous culture was cared for further inoculation.

\section{Screening Tests}

Healthy seedlings of fifty-one tomato inbreed lines, obtained from Tomato Breeding Program of DRC, were evaluated against the infection Egyptian J. Desert Res., 69, Special Issue, 33-46 (2019) 
with RKN, M. incognita. Three-week old of tested plants were singly transplanted in $15 \mathrm{~cm}$ diameter clay pots filled with disinfesting sandy clay soil $(3: 1 \mathrm{v} / \mathrm{v})$. Two weeks later, seedlings were inoculated with approximately 1500 freshly hatched juveniles of $M$. incognita per plant, the inoculation level (1500 juveniles) was proposed according to El-Sherif et al. (2007). Four replicates of each tomato genotype were used for each genotype. The experiment was repeated in two seasons (early winter and summer) during 2018-2019. All pots were arranged in randomized complete block design on a greenhouse bench and received the same fertilization and watered as needed. Fifty days after nematode inoculation, all plants were uprooted and the root system of each plant was washed to remove soil particles by tap water. Nematode parameters were determined as described subsequently.

To rank the tested vegetable plants as susceptible or resistance to RKN we used two scales; the first was a modified gall index, which used for rating the resistance status of tested genotypes according to Nayak and Sharma (2013); no gall, immune (0), 1-15 gall resistant (1), 16-25 gall moderately resistant (2), 26-50 gall moderately susceptible (3), 51-100 gall susceptible (4), heavy galling $100+$ or more highly susceptible (5). The second plants were rated on a (0-5) scale according to the numbers of egg masses/root system or Egg Mass Index (EMI). Plants with $0=$ no egg masses (Immune), 1= 1-2 egg masses/plant were considered resistant $-\mathrm{R}-;$ 2=3-10 egg masses/plant, moderately resistant -MR-; 3=11-30 egg masses/plant, moderately susceptible (MS); 4=31-100 egg masses/plant, susceptible -S-; and 5=>100 egg masses/ root system, highly susceptible -HS- (Taylor and Sasser, 1978).

\section{Nematode Assay}

Roots were stained in lactophenol acid fuchsin (Franklin and Goodey, 1959). Galls and egg-masses were counted under a stereo-zoom microscope using two fine dissecting needles. Number of eggs per egg-mass (fecundity) was counted by picking 10 egg-masses of uniform size from roots, and count each egg mass separately (after put it on glass slide divided into squares with drop of water, examined using a microscope and count eggs by the aid of hand counter) then calculate the mean number of eggs/egg mass. Total eggs/root system were also calculated by multiplying the mean number of eggs/egg mass by number of egg masses/root system for each replicate. The final population (FP) was calculated by summation of egg masses + total eggs and the rates of nematode reproduction or build up (RB) were calculated by dividing the nematode final population $(\mathrm{Pf})$ on the initial population $(\mathrm{Pi})$. 


\section{Statistical Analysis}

Experiment was designed by randomized complete block design (RCBD) with 4 replications. All the data were analyzed by ANOVA (JMP program from SAS version 7.0.1) and significant differences among the means was partitioned by Duncan's multiple range test at $P=0.05$ (Steel et al., 1997).

\section{RESULTS AND DISCUSSION}

Data in table (1) and fig. (1 and 2) show the reaction of fifty-one genotypes of tomato, which screened against RKN infection. In summer experiment, two genotypes viz., SA174-7 and SY174-1, were found to be resistant (R), which recorded a gall index and egg mass index of $1.0 \& 1.0$ and $1.0 \& 2.0$, successively. The differences between two resistant genotypes in gall, E.M. and total eggs count were not significant. Only three tomato genotypes (SK174-4, SW174-4 and SY174-8-3) were categorized as moderate resistant (MR) as they possess 21,19 and 25 gall per root system and 12, 10 and 22 egg masses and total egg numbers 3900, 2601 and 8587, respectively. All nematode criteria of MR genotypes were not statically different. Moderate susceptible (MS) response were observed in 3 inbreed lines namely; SC174-7, SD174-4-1 and SY174-2-2, total egg number was also not statically different. On the other hand, the seven genotypes viz., SB174-3, SB174-1, SD174-1, SD174-5-3, SH74-1, SH174-5-1 and SH174-7 were susceptible (S). The rest genotypes (36) were highly susceptible (HS) hosts. The maximum number of galls/per root was formed in SD174-5-2, SS175-5-2, SA174-2 and SY174-2-1 (805,779, 656 and 588.7, respectively). The maximum number of egg masses was showed in SA174-6, SB174-2 and SY174-2-1 (651, 435 and 521, successively). Data in table (1) also demonstrated that relationship between number of galls and number of egg masses on the same plant not constant or positive in general, except some cases like SY174-2-1 showed higher number of galls (588) and higher number of egg masses (521). In winter trial, the tested genotype similarly reacted as in summer trial with some exceptions; SY174-8-3 ranked as R in winter, while in summer was MR, SC174-1 transferred from S position to MS position and another four genotypes behaved similarly, SH174-1, SH174-5-1, SH174-7, SY174-2-2. Results also showed that the penetration and reproduction of nematode were increased in summer and were retarded in winter at low temperature.

The compatible reaction of the susceptible tomato genotypes towards $M$. incognita infection proved that they lack genes conferring the resistant, so these genotypes allowed to juveniles to penetrate them, grow normally and reproduce. In this study 51 tomato genotypes, obtained from breeding program in DRC, were screened towards the infection with $M$. incognita nematode as a serious biotic stress on tomato plants in Egypt. The

Egyptian J. Desert Res., 69, Special Issue, 33-46 (2019) 


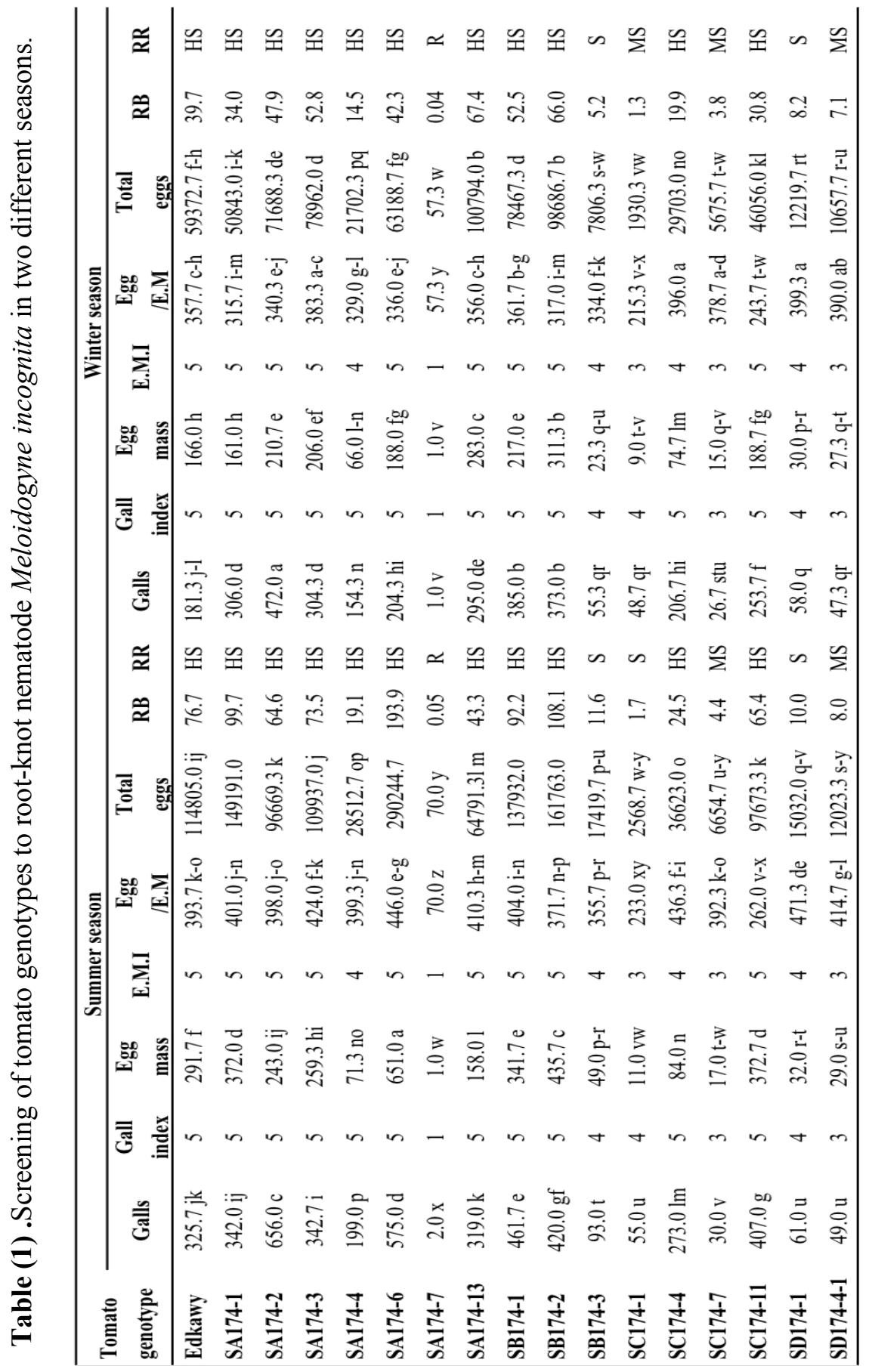

Egyptian J. Desert Res., 69, Special Issue, 33-46 (2019) 


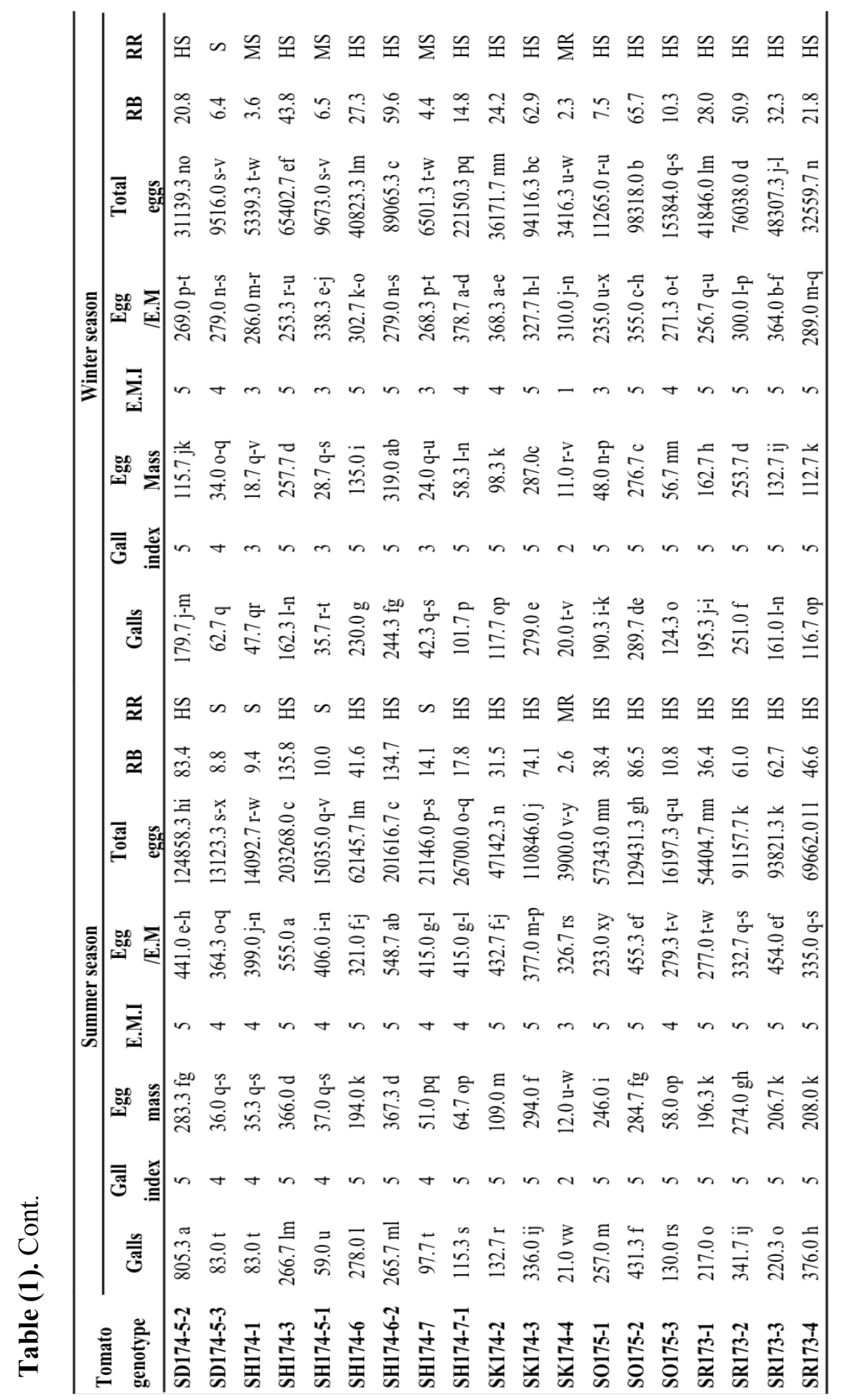

Egyptian J. Desert Res., 69, Special Issue, 33-46 (2019) 


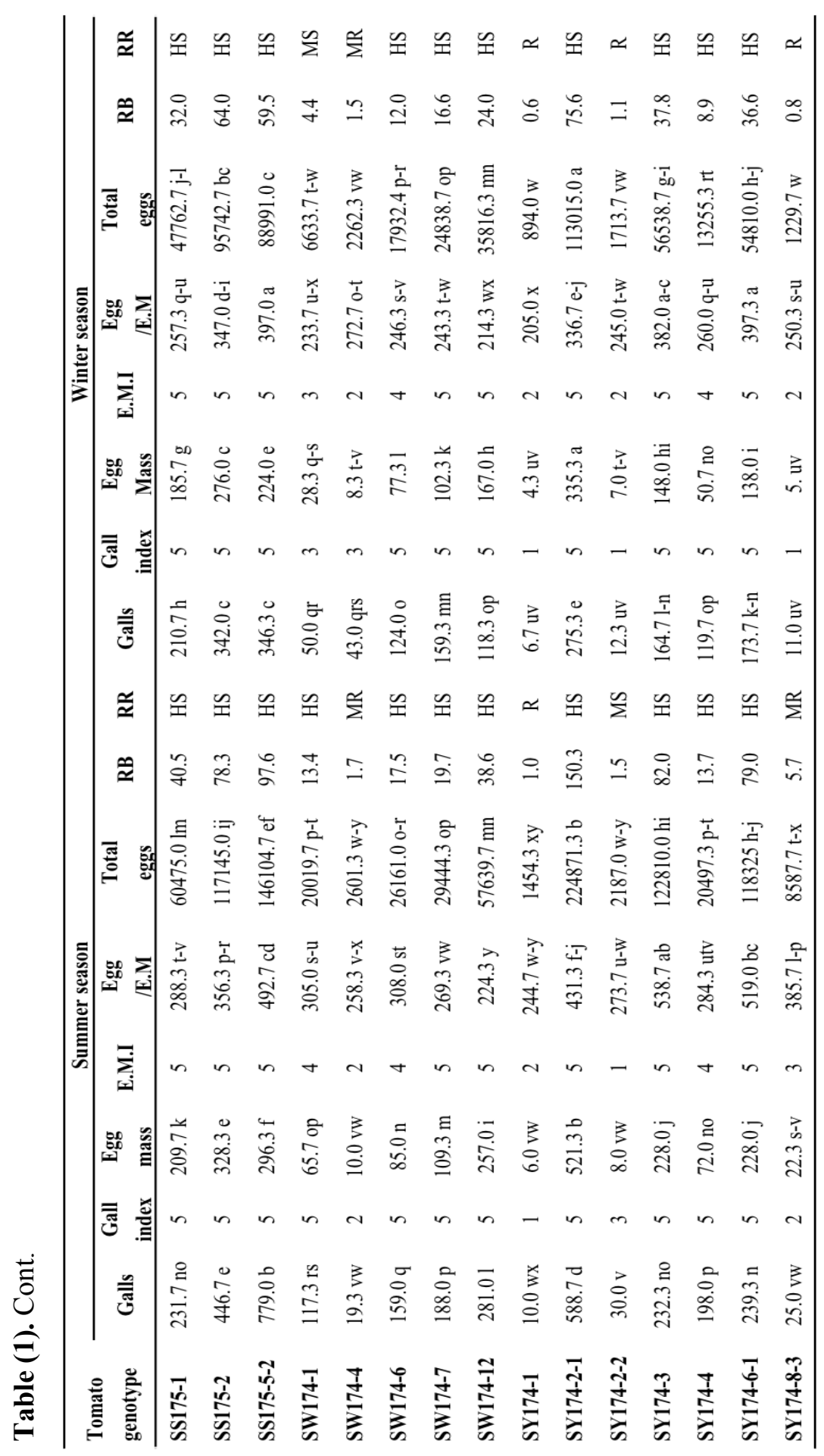

Egyptian J. Desert Res., 69, Special Issue, 33-46 (2019) 


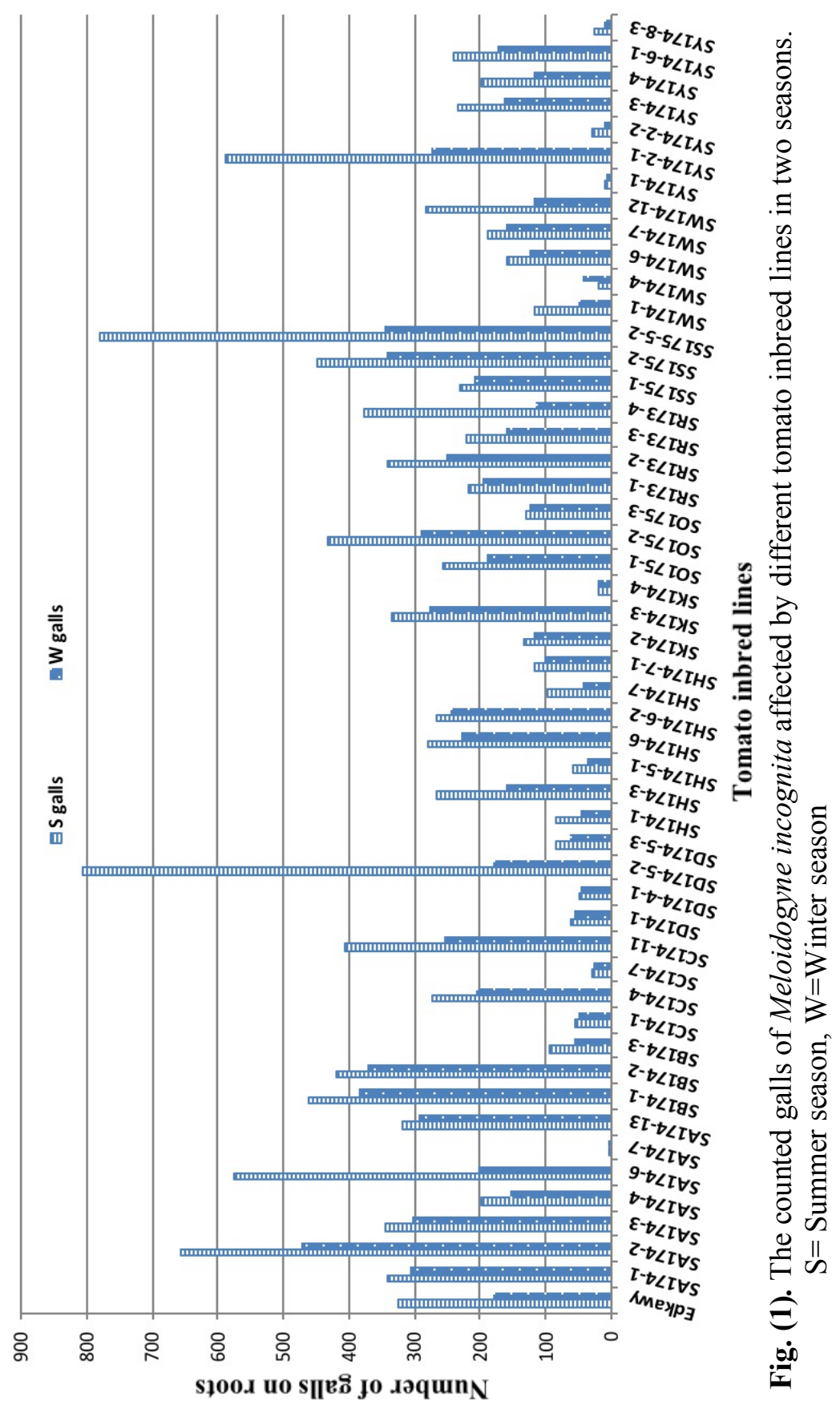

Egyptian J. Desert Res., 69, Special Issue, 33-46 (2019) 


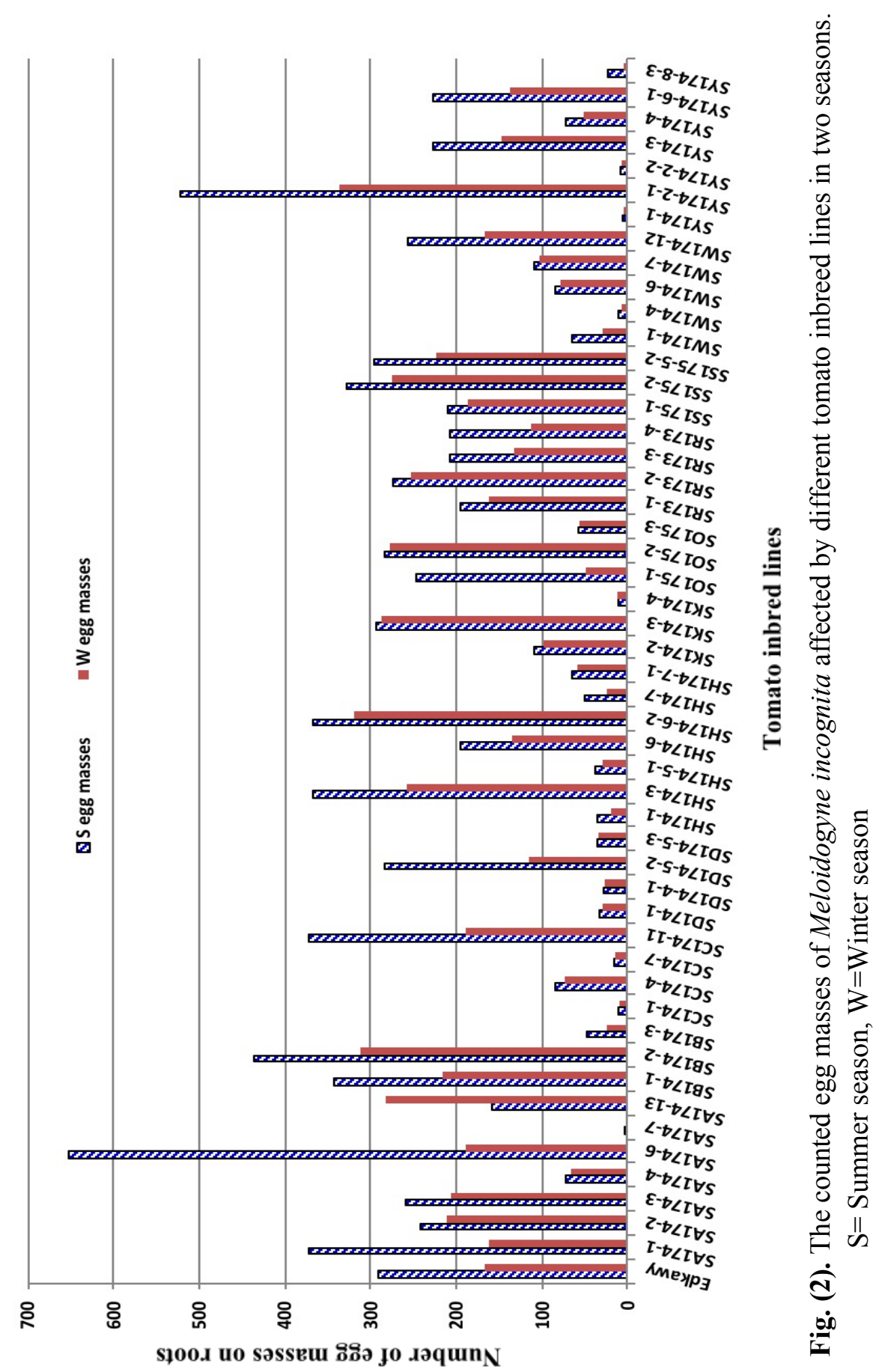

Egyptian J. Desert Res., 69, Special Issue, 33-46 (2019) 
search for new nematode-resistance germplasms must be frequent to manage nematode problems, many scientists mentioned that natural nematode resistance genes present in gene pools of crop species and their relatives have long been exploited with the aim of transferring such characters into economically important crops where effective resistance is lacking (FosuNyarko and Jones, 2015).

The results of the present study are matching with the study of Ibrahim et al. (2014), as they tested the suitability of eight tomato cultivars to RKN and found Castle Rock, Edkawy and Super Marmande were highly susceptible to $M$. incognita as possess high numbers of galls and egg masses/root, while three cultivars viz., Giza 80, Super Crystal and Super Strain B were susceptible. On the other hand, cultivar N 23 was moderately susceptible to the tested nematodes and formed low numbers of galls and egg masses (25-33 and 19-28/ plant, respectively). These results also agree with other researchers, who studied the susceptibility of different tomato cultivars to Meloidogyne spp. (Korayem, 2008; Muhammad et al., 2011; Khanzada et al., 2012; El-Ansary, 2013; Gharabadiyan et al., 2013 and Dharani et al., 2019). Susceptibility and resistance to $M$. incognita reflect the role of the host on the reproduction ability of challenge nematode (Cook and Evans, 1987). In the genotypes viz., SA174-7 and SY174-1 reproduction of nematodes was lower as compared to other inbreed lines as the rate of buildup (RB) was lower than other genotypes ( 0.05 and 1, respectively). Early reports documented that the counted galls and egg masses on roots were higher on susceptible tomato cultivars infested with M. incognita (Pathan et al., 2004).

The temperature has an impact on nematode style and considered to be an important element on egg hatching, nematode exodus, root incursion and progress in host roots as early studied by Tyler (1933). He found that $28^{\circ} \mathrm{C}$ was the optimal temperature for RKN penetration and infection. It was observed that infective stage of Meloidogyne hapla take 14 days from inoculation to be mature in lettuce plants at day temperature about $32^{\circ} \mathrm{C}, 18$ days at $27^{\circ} \mathrm{C}$ and 34 days at $21^{\circ} \mathrm{C}$. Eggs were produced after 20 days from inoculation at high temperature, 26 days at intermediate temperature $27^{\circ} \mathrm{C}$ and 54 at $21^{\circ} \mathrm{C}$. Number of larvae and eggs after 42 days was abundant at $32^{\circ} \mathrm{C}$ than at $27^{\circ} \mathrm{C}$ (Wong and Mai, 1973). Recent investigation of Weimin et al. (2018) showed that, at $31^{\circ} \mathrm{C}$ more juveniles entered Georgia-06G, susceptible peanut cultivar, roots compared with that at $28^{\circ} \mathrm{C}$ and $34^{\circ} \mathrm{C}$. In this study, the temperature of $31^{\circ} \mathrm{C}$ was optimal for $\mathrm{J} 2$ to penetrate and parasitize the Georgia-06Gmm. This discrepancy may due to different RGN species and also because of different host plants being tested. Temperature also has an impact on genes conferring resistance to RGN in plants, which possess Mi-1.2 genes, a nematode resistance gene that is occurred in most tomato varieties, (Araujo et al., 1982). However, Mi-1.2 may lose its potency at soil temperatures above $28^{\circ} \mathrm{C}$ and certain virulent nematode isolates can Egyptian J. Desert Res., 69, Special Issue, 33-46 (2019) 
overcome resistance, even at moderate soil temperatures as formerly reported (Cooper et al., 2005). Also they found that the effects of Mimediated resistance were shortened but not phased out at $32{ }^{\circ} \mathrm{C}$. The compatible reaction of the susceptible and highly susceptible tomato genotypes towards $M$. incognita infection proved that they lack genes conferring the resistant, so these genotypes allowed to juveniles to penetrate them, grow normally and reproduce.

\section{CONCLUSION}

In conclusion, this study indicated that significant differences were observed among the most tested genotypes against the root-knot nematode. The genotypes SA174-7 and SY174-1 were found to be resistant (R) to RGN (M. incognita). So, these genotypes are promising materials to be used as resistant source to RGN. Cultivation of these RGN-resistant genotypes will be a strategic alternative for the production of healthy and pesticide-free tomato. However, further studies should be carried out to ensure these results under naturally infested field conditions. Also, it is necessary to know the relationship between the character of resistant to RGN and other desirable characters especially high productivity. In addition, identifying the genes that govern resistance to nematode and trying to transfer these genes to susceptible tomato genotypes are needed.

\section{REFERENCES}

Anwar, S.A. and M.V. McKenry (2010). Incidence and reproduction of Meloidogyne incognita on vegetable crop genotypes. Pakistan J. Zool., 42: 135-141.

Araujo, M.T., M.J. Bassett, J.J. Augustine and D.W. Dickson (1982). Effect of diurnal changes in soil temperatures on resistance to Meloidogyne incognita in tomato. Journal of Nematololgy,14 (3): 414-416.

Bird, D.M. and I. Kaloshian (2003). Are roots special? Nematodes have their say. Physiol. Mol. Pl. Pathol., 62: 115-23.

Bufokuzara, N.D. (1996). Incidence of different nematodes on vegetable and fruit crops and preliminary assessment of yield loss due to Meloidogyne species in Uganda. Nematol. Brasileira, 2: 32-43.

Cetintas, R. and M. Yarba (2010). Nematicidal effects of five essential plant oils on the southern root-knot nematode, Meloidogyne incognita Race 2. J. Anim.Vet. Adv., 9: 222-225.

Charchar, A.U., J.M. Gonzaga, V. Giordano, L.de. Boiteuy and L.S. Reis (2003). Reaction of tomato cultivars to infection by a mixed population of $M$. incognita race and $M$. javanica in the field. Nematol. Brasileira, 27: 49-54. 
Cook, R. and K. Evans (1987). Resistance and tolerance. In: R.H. Brown and B.R. Kerry (eds.) Principles and practices of nematode control in crops Orlando, Fl. Acad. Press: 179-231.

Cooper, W.R., L. Jia and L. Goggin (2005). Effects of jasmonate-induced defenses on root-knot nematode infection of resistant and susceptible tomato cultivars, J. Chem. Ecol. , 31 (9): 1953-1967.

Dharani, S., P. Kalaiarasan, N. Swarnakumari, V. Premalakshmi and K. Poornima (2019). Comparative evaluation of root-knot nematode, Meloidogyne incognita (Kofoid and White, 1919) Chitwood, 1949 resistance in tomato (Lycopersicon esculentum L.). Journal of Entomology and Zoology Studies, 7 (3): 569-573.

Elling, A.A. (2013). Major emerging problems with minor meloidogyne species. Phytopathology,103 (11): 1092-1102.

El-Ansary, M.S.M. (2013). Susceptibility of different tomato cultivars against root-knot nematode, Meloidogyne spp. Egypt. J. Agronematol., 12 (1): 54-62.

El-Sherif, A.G., A.R. Refaei, M.E. El-Nagar and H.M.M. Salem (2007). The role of eggs inoculum level of Meloidogyne incognita on their reproduction and host reaction. African Journal of Agricultural Research, (2): 159-163.

Fosu-Nyarko, J. and M.G.K. Jones (2015). Chapter fourteen - Application of Biotechnology for Nematode Control in Crop Plants. Advances in Botanical Research, 73: 339-376.

Franklin, M.T. and J.B. Goodey (1959). A cotton-blue lactophenol technique for counting plant parasitic nematodes. J. Helminthol., 23: 175-178.

Gharabadiyan, F., S. Jamali and H.R. Komeili (2013). Determining of rootknot nematode (Meloidogyne javanica) damage function for tomato cultivars. J. Agricultural Sciences, 58 (2): 147-157.

Ibrahim, I.K., W.T. Shahda and O.A. Dawood (1999). Pathogenicity and control of Meloidogyne incognita on Eggplant. Nematologia Mediterranea, 27: 31-33.

Ibrahim, I.K., A.A. Mokbel and Z.A. Handoo (2010). Current status of phytoparasitic nematodes and their host plants in Egypt. Nematropica, 40: 239-262.

Ibrahim, I.K., A.A. Mokbel and S.E. Hammad (2014). Host suitability of some Solanaceous plant cultivars to the root-knot nematodes, Meloidogyne spp. Glo. Adv. Res. J. Agric. Sci., 3 (5): 136-140.

Khanzada, S., M.M. Jiskani, S.R. Khanzada, M.S. Khanzada, S. Ali, K.A. Khanzada, N. Saeed, S. Anwar and M. Khalid (2012). Response of some tomato cultivars against root-knot nematode, Meloidogyne incognita (kofoid and white) chitwood. The Journal of Animal and Plant Sciences, 22 (4): 1076-1080.

Egyptian J. Desert Res., 69, Special Issue, 33-46 (2019) 
Korayem, A.M. (2008). Tolerance limits and damage threshold of Meloidogyne incognita to tomato under different biotic and abiotic factors. Egypt. J. Agronematol., 6 (1): 1-9.

Muhammad, K.; S.A. Anwar and S.A. Khan (2011). Evaluation of tomato genotypes against Meloidogyne incognita infection. Pakistan J. Phytopathology, 23 (1): 31-34.

Nayak, N. and J.L. Sharma (2013). Evaluation of Brinjal (Solanum melongena) varieties for resistance to root-knot nematode Meloidogyne incognita. G.J.B.B., 2 (4): 560-562.

Pathan, M.A., M.M. Jiskani, K.H. Wagan and D.A. Darban (2004). Variability in reproduction of Meloidogyne incognita on selected tomato cultivars. Pakistan J. Nematol., 22: 61-64.

Sikora, R.A. and E. Fernandez (2005). Nematode Parasites of Vegetables. In: "Plant Parasitic Nematodes in Subtropical and Tropical Agriculture". Luc, M., R.A. Sikora and J. Bridge (Eds). $2^{\text {nd }}$ Edition, CABI Publishing, p. 319-392.

Steel, R.G.D., J.H. Torrie and D.A. Dickey (1997). Principles and procedures of statistics. A biometric approach $3^{\text {rd }}$ Ed. McGraw Hill Book Co. Inc., New York.

Sujatha, R., P.I. Vethamoni, N. Manivannan and M. Sivakumar (2017). Screening of tomato genotypes for root-knot nematode (Meloidogyne incognita, Kofoid and White Chitwood). International Journal of Current Microbiology and Applied Sciences, 6 (3): 15251533.

Taylor, A.L. and J.N. Sasser (1978). In "Biology, Identification, and Control of Root-Knot Nematodes (Meloidogyne spp.)," North Carolina State University Graphics, Raleigh.

Tyler, J. (1933). Development of the root-knot nematode as affected by temperature. Hilgardia, 7: 389-415.

Weimin, Y., C.C. Holbrook, Y. Chu, P. Ozias-Akins and D.W. Dickson (2018). Influence of temperature on susceptibility of cvs. Tifguard and Georgia-06G peanut to Meloidogyne arenaria. Journal of Nematology, 50: 33-40.

Wong, T.K. and W.F. Mai (1973). Effect of temperature on growth, development and reproduction of Meloidogyne hapla in lettuce. Journal of Nematology, 2 (5): 139-142. 


\section{تقييم سلالات مرباة من الطماطم ضد الإصابة بنيماتودا تورم الجذور}

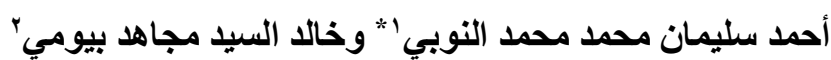

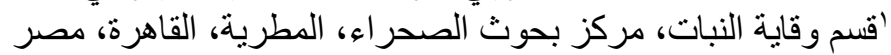

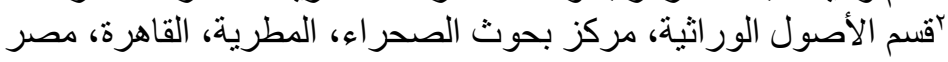

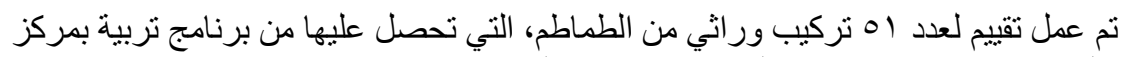

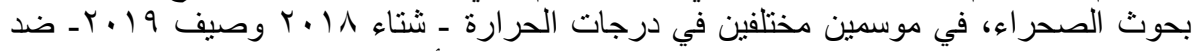

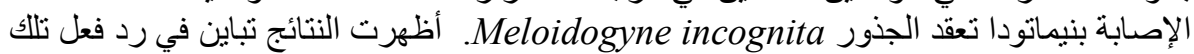

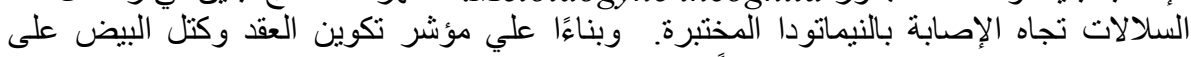

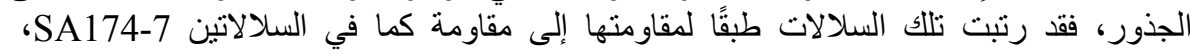
SY74-1

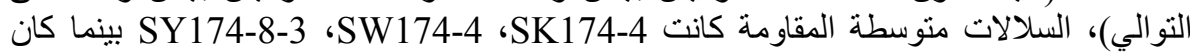

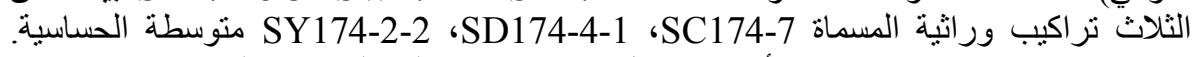

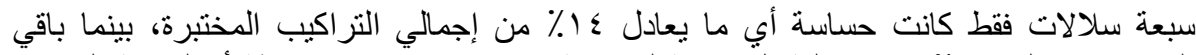

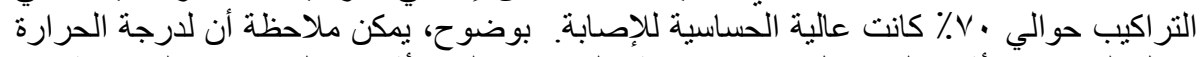

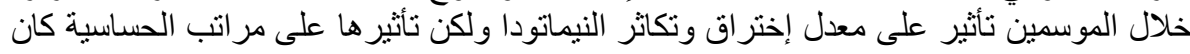

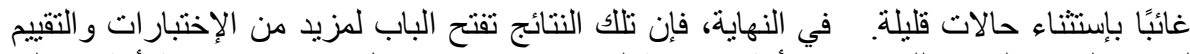

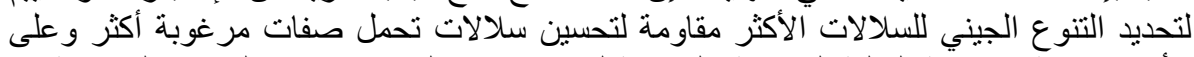

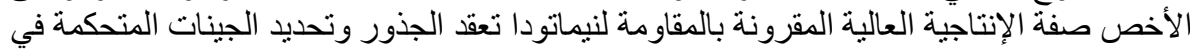
المقاومة لنقلها للتزر اكيب الحساسة من الطماطم.

Egyptian J. Desert Res., 69, Special Issue, 33-46 (2019) 